\title{
Addendum: Lallana, M.J. et al. Use of Non-Steroidal Anti-Inflammatory Drugs and Associated Gastroprotection in a Cohort of Workers. Int. J. Environ. Res. Public Health 2018, 15, 1836
}

\author{
María Jesús Lallana ${ }^{1, *(0)}$, Cristina Feja ${ }^{2}$, Isabel Aguilar-Palacio ${ }^{2}$, , Sara Malo $^{2}$ (1) \\ and María José Rabanaque ${ }^{2}$ (i) \\ 1 Pharmacy Service in Primary Health Care, Aragones Health Service, 50009 Zaragoza, Spain \\ 2 Department of Microbiology, Preventive Medicine and Public Health, University of Zaragoza, \\ 50009 Zaragoza, Spain; cfeja@aragon.es (C.F.); iaguilar@unizar.es (I.A.-P.); smalo@unizar.es (S.M.); \\ rabanake@unizar.es (M.J.R.) \\ * Correspondence: mjlallana@salud.aragon.es; Tel.: +34-976-750-750
}

Received: 17 March 2020; Accepted: 27 November 2020; Published: 3 December 2020

The authors wish to make the following correction to this paper [1]:

\section{Change in Funding}

In the original version of our article (Lallana, M.J. et al. Use of Non-Steroidal Anti-Inflammatory Drugs and Associated Gastroprotection in a Cohort of Workers. 2018, 15, 1836), insufficient source of funding was given. The authors wish to change the information in the Funding section from:

Funding: This study was funded by the Instituto Carlos III, grant number (PI17/01704). to the correct version as follows:

Funding: This study was funded by Proyecto del Fondo de Investigación Sanitaria, Instituto de Salud Carlos III (Ministerio de Ciencia e Innovación) and Fondo Europeo de Desarrollo Regional (FEDER)(PI17/011704).

The authors would like to apologize for any inconvenience caused to the readers by these changes.

\section{Reference}

1. Lallana, M.J.; Feja, C.; Aguilar-Palacio, I.; Malo, S.; Rabanaque, M.J. Use of Non-Steroidal Anti-Inflammatory Drugs and Associated Gastroprotection in a Cohort of Workers. Int. J. Environ. Res. Public Health 2018, 15, 1836. [CrossRef] [PubMed]

Publisher's Note: MDPI stays neutral with regard to jurisdictional claims in published maps and institutional affiliations.

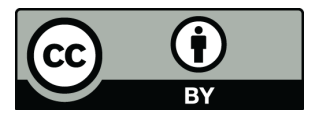

(C) 2020 by the authors. Licensee MDPI, Basel, Switzerland. This article is an open access article distributed under the terms and conditions of the Creative Commons Attribution (CC BY) license (http://creativecommons.org/licenses/by/4.0/). 